\title{
Interfering with mineralocorticoid receptor activation: the past, present, and future
}

\section{Anne M. Dorrance}

Address: Department of Pharmacology and Toxicology, Michigan State University, B340 Life Sciences, 1355 Bogue Street, East Lansing, MI 48824, USA

Email: dorranc3@msu.edu

Fl000Prime Reports 2014, 6:6I (doi:10.12703/P6-6I)

All FI000Prime Reports articles are distributed under the terms of the Creative Commons Attribution-Non Commercial License (http://creativecommons.org/licenses/by-nc/3.0/legalcode), which permits non-commercial use, distribution, and reproduction in any medium, provided the original work is properly cited.

The electronic version of this article is the complete one and can be found at: http://f1000.com/prime/reports/b/6/61

\begin{abstract}
Aldosterone is a potent mineralocorticoid produced by the adrenal gland. Aldosterone binds to and activates the mineralocorticoid receptor (MR) in a plethora of tissues, but the cardiovascular actions of aldosterone are of primary interest clinically. Although MR antagonists were developed as antihypertensive agents, they are now considered to be important therapeutic options for patients with heart failure. Specifically, blocking only the MR has proven to be a difficult task because of its similarity to other steroid receptors, including the androgen and progesterone receptors. This lack of specificity caused the use of the first-generation mineralocorticoid receptor antagonists to be fraught with difficulty because of the side effects produced by drug administration. However, in recent years, several advances have been made that could potentially increase the clinical use of agents that inhibit the actions of aldosterone. These will be discussed here along with some examples of the beneficial effects of these new therapeutic agents.
\end{abstract}

\section{Introduction}

Aldosterone, a mineralocorticoid produced primarily in the adrenal gland, is classically considered to regulate sodium and water balance in the kidney and to control blood pressure. Increases in plasma aldosterone lead to sodium retention, potassium excretion, and hypertension. In recent years, it has become clear that aldosterone, or activation of its receptor, the MR, has several extrarenal effects that are largely detrimental, at least in the setting of heart disease [1-3] and hypertension [4,5]. The increasing knowledge of the effects of aldosterone on the cardiovascular system in particular has led to a renewed interest in developing ways to block its actions. This has led to the development of several new drugs that can potentially interfere with MR signaling. These will be discussed here; for each drug class, I have selected recent studies describing the effects of the drug to highlight their potential usefulness in the treatment of cardiovascular conditions. I will discuss the classic steroidal MR antagonists-spironolactone and eplerenone-and the newer non-steroidal antagonists. I will also discuss the progress in the development of aldosterone synthase inhibitors and will consider the rapid non-genomic effects of aldosterone and their inhibition. The potential sites for inhibition of the actions of aldosterone are summarized in Figure 1.

\section{The basics of adrenal biology and the mineralocorticoid receptor}

Before discussing the ways to interfere with the aldosterone/MR system, it is first necessary to describe a little of the basic biology of the system. Aldosterone is produced primarily in the adrenal zona glomerulosa. There is some evidence that other tissues, including the vasculature, heart, brain, and adipose tissues, produce aldosterone [6-13]. However, these findings are controversial and have largely been refuted $[14,15]$.

Aldosterone secretion is controlled by several factors. The most prominent are angiotensin II and potassium. Increases in both of these factors cause an increase in the production of aldosterone, but the actions of angiotensin II and potassium are independent of each other [16]. Acute 
Figure I. Schematic of the potential sites for inhibiting the actions of aldosterone/mineralocorticoid receptor activation

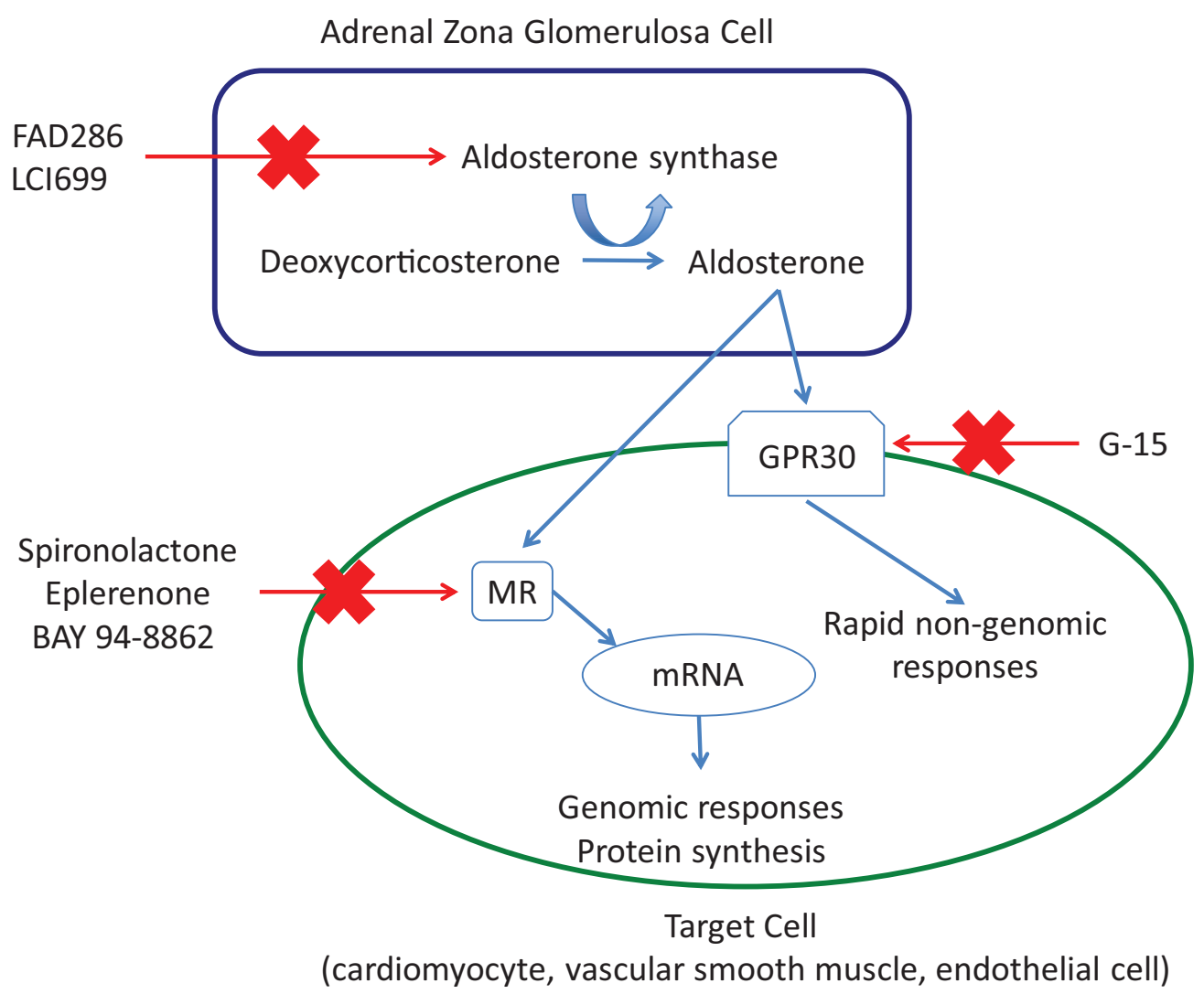

Abbreviations: MR, mineralocorticoid receptor.

increases in the adrenocorticotrophic hormone (ACTH) also increase aldosterone production, but sustained stimulation of the adrenal gland with ACTH inhibits aldosterone production [16]. There are several other aldosterone secretagogues, which include endothelin, vasopressin, and serotonin; these are less potent than angiotensin II and potassium and their physiological roles remain ill-defined [17].

Aldosterone causes its effects by binding to the MR. The MR belongs to the steroid receptor superfamily that contains the progesterone, estrogen, androgen, and glucocorticoid receptors [18]. These receptors have a common structure, and this has made the development of highly specific MR antagonists difficult. The MR is unique in this family in that it has two ligandsaldosterone and cortisol (or corticosterone in rodents)that bind to the MR with the same affinity [19]. In epithelial tissues, the $11 \beta$ hydroxysteroid dehydrogenase type II (11ßHSD2) protects the MR from being occupied by glucocorticoids that circulate at much higher concentrations than aldosterone [20]. The 11ßHSD2 metabolizes cortisol to cortisone in humans, cortisone cannot bind to the MR, therefore, when 11ßHSD2 is active, aldosterone can bind to and activate the MR. If $11 \beta \mathrm{HSD} 2$ is not present or not functional, the ligand binding site on the MR is occupied by cortisol. Several non-epithelial MR-expressing tissues, including the heart, adipocytes, and macrophages, do not express 113HSD2 and, therefore, in these tissues, the MR is occupied predominantly by cortisol [21]. There have been several excellent review articles describing the pre-receptor regulation of MR signaling [20,22]. The MR has been the least studied of the steroid receptor family (for reviews of MR signaling, see [18,23]). The status of the MR as the "Cinderella" of the steroid receptors changed when two groundbreaking clinical studies showed that MR activation is involved in the pathogenesis of cardiovascular disease $[3,24]$. These trials showing that spironolactone and eplerenone reduced the morbidity and mortality in patients with heart failure and left ventricular dysfunction led to a renewed interest in MR biology and to a new search for novel ways to inhibit the system. There is a real interest in finding ways to inhibit the cardiovascular effects of MR activation, while leaving the physiological 
effects on the kidney intact. Interestingly, although the scientific community is convinced of the beneficial effects of MR antagonism, the molecular mechanisms responsible for the effects of aldosterone/MR activation have not been completely elucidated. It is clear, however, that aldosterone/ $M R$ activation increases reactive oxygen species production and vascular inflammation [25].

\section{Classic mineralocorticoid receptor antagonists}

The competitive MR antagonist spironolactone was developed as an antihypertensive agent in the 1950s and became commercially available in 1960. Although spironolactone is a potent MR antagonist, it also binds to other members of the steroid receptor family. It has significant antiandrogenic and progestogenic effects [26] that lead to gynecomastia, impotence, and menstrual irregularities [27-29]. The side effects associated with spironolactone meant that there was a need for a more selective MR antagonist that could mimic the beneficial effects of spironolactone in the population with essential hypertension without the related side effects [30]. The search for this drug led to the development of eplerenone, which entered phase 1 clinical trials in 1986 [31] and was first marketed in the United States in 2002. Although eplerenone is a more selective MR antagonist than spironolactone, it has a 40 -fold lower affinity for the receptor, which makes it a less potent antagonist than spironolactone [32,33]. It seems that the 42 years from the approval of spironolactone to the approval of the second-generation drug is a pharmaceutical industry record [34]. Even with this really long wait, it is not clear that the successor is any better than the parent compound for the treatment of human hypertension $[35,36]$. However, it should be noted that the long search for new MR blockers yielded some other useful drugs, including drospirenone, which has progestogenic activity and is included in several forms of birth control pills [37].

One of the differences between spironolactone and eplerenone is their metabolism. Spironolactone is metabolized to two compounds, which also have anti-MR activity [32], whereas eplerenone has no active metabolites [38]. One of the active metabolites of spironolactone, canrenone [39], is currently in clinical use and effectively reduces blood pressure, insulin resistance, and markers of inflammation in patients with metabolic syndrome [40]. From an experimental standpoint, several labs, including our own, have begun to utilize canrenone or potassium canrenoate, which is converted to canrenone, in long-term animal studies because of their ease of administration. Both can be administered in the drinking water without the need for additional vehicles $[41,42]$. Importantly, canrenone has less anti-androgenic effects than spironolactone [43-45].
One of the suggested mechanisms responsible for the beneficial effects of MR antagonists is a reduction in vascular inflammation. It has been clear for some time that inflammation is increased in mineralocorticoiddependent hypertension, such as the deoxycorticosterone (DOCA)-salt hypertensive rats and much of this research has focused on macrophages. Early studies showed that MR activation increases intracellular adhesion molecule-1 (ICAM-1) expression and leukocyte adhesion in endothelial cells [46], and we have shown that spironolactone reduces ICAM-1 messenger RNA (mRNA) expression in cerebral arteries from hypertensive rats [47]. Vascular smooth muscle and endothelial cells express 11ßHSD2; therefore, in these studies, the MR is likely to be occupied and activated by aldosterone [48-51]. Several studies have shown that MR activation is linked to macrophage infiltration into the heart in DOCA-salt rats and that eplerenone inhibits this action [52-54]. More recent studies of the effects of MR activation on macrophages have focused on the MR within the macrophage itself and on the concept that MR activation can alter macrophage polarity, leading to a more proinflammatory phenotype. The first studies using myeloid cell-specific MR knockout mice were published by Rickard and colleagues [55] in 2009. Later studies using myeloid cell-specific MR knockout mice showed that, in the absence of the MR, the macrophages took on an anti-inflammatory wound-healing phenotype [56]. Macrophages do not express 11ßHSD2; therefore, in these cells, it is likely that the MR is occupied by glucocorticoids $[57,58]$. It is, however, interesting that MR antagonism with eplerenone in macrophages from healthy patients and patients with heart failure does not completely recapitulate the effects of genetic ablation of the MR $[59,60]$.

Although most studies have focused on macrophages, some studies suggest that $\mathrm{T}$ cells are also an important part of the vascular inflammatory response associated with hypertension [61]. Recent studies assessed the mechanisms responsible for $\mathrm{T}$ cell activation in DOCA-salt hypertensive rats. These studies showed that MR activation caused the activation of T helper 17 (Th17) cells and a downregulation of regulatory $\mathrm{T}$ (Treg) cells; this occurred in a blood pressure-independent manner. Spironolactone ameliorated the response to DOCA-salt, but blood pressure lowering through a non-renin angiotensin II-dependent mechanism had no effect. This suggests that the effects of spironolactone on the T cell populations are MR - and not blood pressure - dependent. Interestingly, the authors suggest that the Th17/interleukin-17 response to MR activation may precede the macrophage infiltration described above [62]. 


\section{Non-steroidal mineralocorticoid receptor antagonists}

MR blockade is useful in patients with heart failure and chronic kidney disease $[3,24,63]$. However, the risk of side effects, hyperkalemia development, and renal dysfunction makes eplerenone and spironolactone the least frequently prescribed medications among all those recommended for the treatment of heart failure [64-68]. This means that the search for new MR antagonists has been focused on finding drugs that have greater effects on the heart than on the kidney. This is essentially a repurposing of MR antagonists; they have moved on from their initial roles as blood pressure-lowering agents to become cardioprotective agents. Several pharmaceutical companies, including Pfizer (New York, USA), Bayer (Leverkusen, Germany), Novartis (Basel, Switzerland), and Takeda (Osaka, Japan), have developed non-steroidal MR antagonists with varying degrees of success [69]. The goal of these companies was to identify compounds with greater specificity at the MR than spironolactone but that were more efficacious than eplerenone.

Interestingly, some of the answers to this question were found in a class of drug that was already in use clinically. The dihydropyridines, which are L-type calcium channel blockers, were found to act as MR antagonists in vitro and in vivo [70-73]. This led to a surge of drug development activity using the basic structure of the dihydropyridines as a backbone for the development of new drugs. For Bayer, this led to the development of BAY 94-8862 [74]. This drug, also known as finerenone, is a potent antagonist at the human $\mathrm{MR}$; it has a half maximal inhibitory concentration $\left(\mathrm{IC}_{50}\right)$ of $18 \mathrm{nM}$ for the $\mathrm{MR}$ and no activity at any of the other steroid hormone receptors or at 65 other receptors and ion channels [74]. Phase 2 clinical trials in patients with heart failure and chronic kidney disease have been conducted [75] (NCT01345656). Thus far, the results of this trial appear favorable. The mineralocorticoid Receptor Antagonist Tolerability Study (ARTS) assessed the safety and tolerability of BAY 94-8862 in patients with reduced left ventricular ejection fraction and chronic kidney disease [76]. Although the trial was too short to assess mortality from heart failure, the analysis of cardiac markers of failure, including brain natriuretic peptide (BNP) and N-terminal pro-BNP, suggests beneficial cardiovascular effects of BAY 94-8862. The incidence of hyperkalemia and reduced renal function was lower in the patients treated with BAY 94-8862 than it was in patients treated with spironolactone [76]. The choice of spironolactone as the comparator drug is, however, considered to be a negative feature of this study. In the future, it will be important to conduct a head-to-head comparison between BAY 94-8862 and eplerenone [77]. Preclinical studies using BAY 94-8862 are also producing promising results. A recent study using rats with mineralocorticoid-dependent hypertension and rats with heart failure showed that BAY 94-8862 has remarkable effects at very low doses. This study was a head-to-head comparison with eplerenone, and the authors matched the drugs for natriuretic effects. The authors found that the tissue distribution of BAY 94-8862 is different than that for eplerenone. Spironolactone and eplerenone preferentially accumulate in the kidney compared with the heart [69], whereas BAY 94-8862 accumulates in both organs to a similar extent [78]. This differential accumulation pattern may be part of the reason why the patients in the ARTS trial experienced less renal dysfunction when taking BAY 94-8862 compared with spironolactone [76]. Interestingly, BAY 94-8862 does not appear to be as good an antihypertensive agent as eplerenone. It appears that, although BAY 94-8862 does not lower blood pressure, its effects on the heart are much more marked than those of eplerenone: cardiac hypertrophy, fibrosis, and pro-BNP expression were diminished by BAY 94-8862. BAY 94-8862 also had marked beneficial effects on the kidney. The cardiac injury in a chronic myocardial infarction model was also significantly reduced by BAY 94-8862 [78]. In this study, the fact that BAY 94-8862 did not cause as large a reduction in blood pressure as spironolactone was considered a positive because in patients with worsening heart failure, the blood pressure is already low [66].

\section{Aldosterone synthase inhibitors}

There are several reasons to consider aldosterone synthase inhibitors as potential therapeutic agents for hypertension and heart failure. The issues with side effects from the steroidal MR antagonists and the need to identify a way to inhibit both the genomic and non-genomic actions (see below) of aldosterone make inhibiting aldosterone production an attractive concept [79]. Also, some patients receiving angiotensin-converting enzyme inhibitors (ACEIs) or angiotensin receptor blockers (ARBs) experience aldosterone breakthrough, where aldosterone levels increase with drug administration [80,81]; this negative effect of ACEIs and ARBs could be negated by blocking the production of aldosterone. The development of an aldosterone synthase inhibitor has been a particularly difficult task to achieve. The enzyme aldosterone synthase, encoded by the CYP11B2 gene, catalyzes the rate-limiting step in aldosterone production, the conversion of deoxycorticosterone to aldosterone. One of the major issues associated with producing a direct inhibitor of this enzyme is the homology it shares with the $11 \beta$ hydroxylase enzyme (CYP11B1), which is the rate-limiting step in cortisol production. At the amino acid level, there is 93\% homology between the two enzymes in humans [82]. Thus, a non-specific inhibitor could interfere with cortisol production and this could impair the stress response 
while also impacting the inflammatory response and metabolism.

The search for a specific aldosterone synthase blocker has led to the development of two potential therapeutic candidates. FAD286 showed great potential initially in preclinical trials where it was shown to reduce aldosterone production [83] and to have beneficial effects in various models of hypertension and heart failure [84-86]. Unfortunately, FAD286 was also found to have significant inhibitory effects on cortisol production and this limits the clinical usefulness of this compound [87].

This led to the development of LCI699, an aldosterone synthase inhibitor that is similar in structure to FAD286 but is approved for human use. This inhibitor is currently in phase 2 clinical trials, and the results are mixed. Although LCI699 inhibits aldosterone production, there is some evidence that it might inhibit $11 \beta$ hydroxylase but that the inhibition is not significant enough to reduce baseline plasma cortisol levels. This was evidenced by an increase in plasma ACTH levels and an impairment in cortisol production in response to ACTH stimulation [88]. Despite the potential effects on cortisol production, LCI699 was deemed safe and well tolerated. A recent clinical trial comparing the effects of LCI699 and eplerenone was conducted in 534 patients with mild to moderate primary hypertension. LCI699 produced a dose-dependent reduction in systolic blood pressure but was no better at reducing blood pressure than eplerenone. The same potential effects on cortisol production were observed in this study [89]. A second study of patients with essential hypertension confirmed the antihypertensive effects of LCI699 [90]. Other studies, however, have failed to show a significant reduction in blood pressure with LCI699-treated patients with resistant hypertension [91]. In a head-to-head comparison, it seems that at least at the level of reducing blood pressure, LCI699 is no better than eplerenone [89,92]. This finding, combined with the fact the LCI699 may have significant effects on cortisol production and, therefore, the stress response, suggests that the drug may be of limited clinical use for the treatment of hypertension. However, LCI699 is currently being promoted as a drug for the treatment of Cushing's syndrome [93]. It is possible that second-generation inhibitors will be more specific with fewer effects on cortisol synthesis.

\section{Non-genomic actions of aldosterone and G protein-coupled estrogen receptor}

Several groups have proposed that aldosterone also induces rapid responses that are non-genomic in nature; that is, they do not require gene transcription and translation; these have recently been reviewed [94-97]. Second messenger pathways such as cyclic adenosine monophosphate, diacylglycerol, inositol triphosphate, and calcium are activated by aldosterone within seconds to minutes of the initial exposure to the steroid [98-101]. Similarly, activation of protein kinases occurs rapidly [102-106]. The receptors responsible for these actions have been difficult to identify. This area of MR receptor biology is reviewed particularly well by Grossmann and Gekle [96], who present a clear argument for most of the non-genomic effects of aldosterone occurring through the classic MR, and as such, these effects can be blocked by classic MR antagonists.

However, recent studies have shown that the G proteincoupled estrogen receptor (GPER), which was initially known as GPR30, may be responsible for some of the rapid non-genomic responses to aldosterone in endothelial [107] and vascular smooth muscle cells [108]. Specific agonists and antagonists have been developed for GPER. The agonist G-1 was identified in 2006 by a combination of virtual and molecular screening using COS7 cells. G-1 is a non-steroidal molecule that has a high affinity and selectivity for the GPER [109]. G-1 mimics the rapid actions of aldosterone in endothelial and smooth muscle cells. These effects include ERK (extracellular-signal-regulated kinases) phosphorylation and apoptosis $[107,108]$. The GPER antagonist, known as G-15, is a G-1 analogue that was first identified in 2009 [110]. This compound effectively inhibits the rapid actions of aldosterone on vascular smooth muscle and endothelial cells $[107,108]$. Having both of these drugs available is a significant advance in helping delineate the rapid non-genomic effects of aldosterone from the slower classic effects requiring gene transcription and translation. These drugs have been used primarily in cell culture, and, therefore, it is not clear how important the rapid non-genomic responses mediated by aldosterone are in the pathology of the aldosteronemediated conditions. G-1 has been chronically administered to female hypertensive rats; this activation of the GPER caused a reduction in blood pressure [111]. The mechanism responsible for this antihypertensive effect of G-1 appears to be direct dilation of resistance arteries [112]. It is difficult to reconcile these findings with the accepted pro-hypertensive effects of aldosterone; clearly, additional studies need to be conducted to delineate the estrogenmediated effects from the aldosterone-mediated effects of GPER activation. There are several other studies that show direct vasodilator properties of aldosterone, but there appear to be an equal number of studies showing direct effects of aldosterone to inhibit dilation or cause constriction $[113,114]$. A recent review of the literature in this area suggests that aldosterone causes nitric oxide 
(NO)-mediated dilation in arteries from healthy individuals; but when endothelial dysfunction is present, aldosterone promotes vasoconstriction [115]. This concept is well described in a study by Heylen and colleagues [116]. This study utilized arterioles from normotensive Wistar rats, aldosterone produced an endothelium-dependent dilation that could be inhibited by spironolactone. Inhibiting NO production also prevented the aldosterone-mediated dilation, thus it appears that aldosterone stimulates vasodilation by activating NO production. However, when the authors removed the endothelium from the arteriole to simulate endothelial dysfunction, they observed a small contractile response to aldosterone administration.

\section{The future of aldosterone/mineralocorticoid receptor blockade}

The publication of the Randomized Aldactone Evaluation Study (RALES) trial in 1999 [24] and the work of Karl Weber (for selected references, see [117-121]) sparked the renaissance of aldosterone research. Around this time, it also became clear that hyperaldosteronism, or an increase in the renin-to-aldosterone ratio, was more prevalent in patients with hypertension than previously predicted [122-126]. Since then, the field has taken huge leaps forward with the identification of non-steroidal MR antagonists, aldosterone synthase blockers, and blockers of the non-genomic actions of aldosterone. However, several unknowns remain. The physiological relevance of the rapid non-genomic responses to aldosterone is not clear. Definitively identifying the receptor for the non-genomic actions of aldosterone is a necessary first step in developing highly specific drugs to inhibit these actions.

The evidence that aldosterone has detrimental effects on the vasculature and the heart has certainly been clear for some time [5,25], but aldosterone has also been recently implicated in other conditions, including cognitive impairment [127]. It seems that exciting times are ahead for aldosterone/MR biology.

\section{Abbreviations}

$11 \beta$ HSD2, $11 \beta$ hydroxysteroid dehydrogenase type II; ACEI, angiotensin-converting enzyme inhibitor; ACTH, adrenocorticotrophic hormone; $\mathrm{ARB}$, angiotensin receptor blocker; ARTS, minerAlocorticoid Receptor Antagonist Tolerability Study; BNP, brain natriuretic peptide; DOCA, deoxycorticosterone; GPER, G protein-coupled estrogen receptor; ICAM-1, intracellular adhesion molecule-1; MR, mineralocorticoid receptor; NO, nitric oxide; Th17, T helper 17.

\section{Disclosures}

The author declares that she has no disclosures.

\section{Acknowledgments}

Anne M. Dorrance is the recipient of an American Heart Association grant-in-aid (13GRNT1721000).

\section{References}

I. Shen JZ, Young MJ: Corticosteroids, heart failure, and hypertension: a role for immune cells? Endocrinology 2012, I 53:5692-700.

2. Funder JW: RALES, EPHESUS and redox. J Steroid Biochem Mol Biol 2005, 93:121-5.

3. Pitt B, Remme W, Zannad F, Neaton J, Martinez F, Roniker B, Bittman R, Hurley S, Kleiman J, Gatlin M: Eplerenone, a selective aldosterone blocker, in patients with left ventricular dysfunction after myocardial infarction. N Engl J Med 2003, 348: I 309-2I.

\section{FIOOOPrime} RECOMMENDED

4. Funder JW: Mineralocorticoid-receptor blockade, hypertension and heart failure. Nat Clin Pract Endocrinol Metab 2005, I:4-5.

5. McGraw AP, McCurley A, Preston IR, Jaffe IZ: Mineralocorticoid receptors in vascular disease: connecting molecular pathways to clinical implications. Curr Atheroscler Rep 2013, I 5:340.

6. Hatakeyama H, Miyamori I, Fujita T, Takeda Y, Takeda R, Yamamoto $\mathrm{H}$ : Vascular aldosterone. Biosynthesis and a link to angiotensin II-induced hypertrophy of vascular smooth muscle cells. J Biol Chem 1994, 269:243 I6-20.

7. Hatakeyama H, Miyamori I, Takeda Y, Yamamoto H, Mabuchi H: The expression of steroidogenic enzyme genes in human vascular cells. Biochem Mol Biol Int 1996, 40:639-45.

8. Takeda Y, Miyamori I, Yoneda T, Iki K, Hatakeyama H, Blair IA, Hsieh FY, Takeda R: Production of aldosterone in isolated rat blood vessels. Hypertension 1995, 25:170-3.

9. Takeda Y, Miyamori I, Inaba S, Furukawa K, Hatakeyama H, Yoneda T, Mabuchi $H$, Takeda $R$ : Vascular aldosterone in genetically hypertensive rats. Hypertension 1997, 29:45-8.

10. Silvestre JS, Robert V, Heymes C, Aupetit-Faisant B, Mouas C, Moalic JM, Swynghedauw B, Delcayre C: Myocardial production of aldosterone and corticosterone in the rat. Physiological regulation. J Biol Chem 1998, 273:4883-91.

II. Takeda Y, Yoneda T, Demura M, Miyamori I, Mabuchi H: Cardiac aldosterone production in genetically hypertensive rats. Hypertension 2000, 36:495-500.

12. Ye P, Kenyon CJ, MacKenzie SM, Jong AS, Miller C, Gray GA, Wallace A, Ryding AS, Mullins J], McBride MW, Graham D, Fraser R, Connell, JMC, Davies E: The aldosterone synthase (CYPI I B2) and I I beta-hydroxylase (CYPI IB I) genes are not expressed in the rat heart. Endocrinology 2005, 146:5287-93.

13. Briones AM, Nguyen Dinh Cat, Aurelie, Callera GE, Yogi A, Burger D, He Y, Corrêa JW, Gagnon AM, Gomez-Sanchez CE, GomezSanchez EP, Sorisky A, Ooi TC, Ruzicka M, Burns KD, Touyz RM: Adipocytes produce aldosterone through calcineurindependent signaling pathways: implications in diabetes mellitus-associated obesity and vascular dysfunction. Hypertension 2012, 59:1069-78.

FlOOOPrime RECOMMENDED

14. MacKenzie SM, Connell, John MC, Davies E: Non-adrenal synthesis of aldosterone: a reality check. Mol Cell Endocrinol 2012, 350:163-7.

15. MacKenzie SM, Huda SS, Sattar N, Fraser R, Connell, John MC Davies E: Depot-specific steroidogenic gene transcription in human adipose tissue. Clin Endocrinol (Oxf) 2008, 69:848-54.

16. Williams GH: Aldosterone biosynthesis, regulation, and classical mechanism of action. Heart Fail Rev 2005, 1 0:7-13.

17. Namsolleck P, Unger T: Aldosterone synthase inhibitors in cardiovascular and renal diseases. Nephrol Dial Transplant 2014, 29(Suppl I):i62-i68. 
18. Gekle M, Bretschneider M, Meinel S, Ruhs S, Grossmann C: Rapid mineralocorticoid receptor trafficking. Steroids 2014, 8I:I03-8.

19. Funder JW: Why are mineralocorticoid receptors so nonselective? Curr Hypertens Rep 2007, 9: I I 2-6.

20. Fuller PJ, Yao Y, Yang J, Young MJ: Mechanisms of ligand specificity of the mineralocorticoid receptor. J Endocrinol 20I2, 2 I3:15-24.

21. Odermatt A, Atanasov AG: Mineralocorticoid receptors: emerging complexity and functional diversity. Steroids 2009, 74: I63-7I.

22. Chapman K, Holmes M, Seckl J: II $\beta$-hydroxysteroid dehydrogenases: intracellular gate-keepers of tissue glucocorticoid action. Physiol Rev 2013, 93:1 I39-206.

23. Lathe R, Kotelevtsev $Y$ : Steroid signaling: ligand-binding promiscuity, molecular symmetry, and the need for gating. Steroids 2014, 82:14-22.

24. Pitt B, Zannad F, Remme WJ, Cody R, Castaigne A, Perez A, Palensky J, Wittes ]: The effect of spironolactone on morbidity and mortality in patients with severe heart failure. Randomized Aldactone Evaluation Study Investigators. N Engl J Med 1999, 341:709-17.

25. Brown NJ: Contribution of aldosterone to cardiovascular and renal inflammation and fibrosis. Nat Rev Nephrol 2013, 9:459-69.

26. Corvol P, Michaud A, Menard J, Freifeld M, Mahoudeau J: Antiandrogenic effect of spirolactones: mechanism of action. Endocrinology 1975, 97:52-8.

27. Greenblatt DJ, Koch-Weser J: Gynecomastia and impotence: complications of spironolactone therapy. JAMA 1973, 223:82.

28. Stripp B, Taylor AA, Bartter FC, Gillette JR, Loriaux DL, Easley R, Menard RH: Effect of spironolactone on sex hormones in man. J Clin Endocrinol Metab 1975, 41:777-81.

29. Levitt Jl: Spironolactone therapy and amenorrhea. JAMA 1970, 2 I I:20|4-5.

30. Jeunemaitre X, Chatellier G, Kreft-Jais C, Charru A, DeVries C, Plouin PF, Corvol P, Menard J: Efficacy and tolerance of spironolactone in essential hypertension. Am J Cardiol 1987, 60:820-5.

31. Gasparo M de, Whitebread SE, Preiswerk G, Jeunemaître X, Corvol P, Ménard J: Antialdosterones: incidence and prevention of sexual side effects. J Steroid Biochem 1989, 32:223-7.

32. Garthwaite SM, McMahon EG: The evolution of aldosterone antagonists. Mol Cell Endocrinol 2004, 2 I 7:27-3I.

33. Hu X, Li S, McMahon EG, Lala DS, Rudolph AE: Molecular mechanisms of mineralocorticoid receptor antagonism by eplerenone. Mini Rev Med Chem 2005, 5:709-I8.

34. Ménard J: The 45-year story of the development of an antialdosterone more specific than spironolactone. Mol Cell Endocrinol 2004, 2 I 7:45-52.

35. Weinberger MH, Roniker B, Krause SL, Weiss RJ: Eplerenone, a selective aldosterone blocker, in mild-to-moderate hypertension. Am J Hypertens 2002, I 5:709-I6.

36. Parthasarathy HK, Ménard J, White WB, Young WF, Williams GH, Williams B, Ruilope LM, Mclnnes GT, Connell JM, MacDonald TM: A double-blind, randomized study comparing the antihypertensive effect of eplerenone and spironolactone in patients with hypertension and evidence of primary aldosteronism. J Hypertens 20II, 29:980-90.

37. Lopez LM, Kaptein AA, Helmerhorst FM: Oral contraceptives containing drospirenone for premenstrual syndrome. Cochrane Database Syst Rev 2012, 2:CD006586.

38. Cook CS, Berry LM, Bible RH, Hribar JD, Hajdu E, Liu NW: Pharmacokinetics and metabolism of [ $14 \mathrm{C}]$ eplerenone after oral administration to humans. Drug Metab Dispos 2003, 3 I: | 448-55.

39. Sadée W, Dagcioglu M, Riegelman S: Fluorometric microassay for spironolactone and its metabolites in biological fluids. J Pharm Sci 1972, 61:1 I26-9.

40. Derosa G, Bonaventura A, Bianchi L, Romano D, D'Angelo A, Fogari E, Maffioli P: Effects of canrenone in patients with metabolic syndrome. Expert Opin Pharmacother 2013, I4:216I-9.
4I. Northcott CA, Fink GD, Garver H, Haywood JR, LaimonThomson EL, McClain JL, Pires PW, Rainey WE, Rigsby CS, Dorrance AM: The development of hypertension and hyperaldosteronism in a rodent model of life-long obesity. Endocrinology 2012, I53:1764-73.

42. Young M, Funder J: Mineralocorticoid action and sodiumhydrogen exchange: studies in experimental cardiac fibrosis. Endocrinology 2003, I44:3848-5I.

43. Armanini D, Sabbadin C, Donà G, Clari G, Bordin L: Aldosterone receptor blockers spironolactone and canrenone: two multivalent drugs. Expert Opin Pharmacother 2014, I5:909-I2.

44. Armanini D, Karbowiak I, Goi A, Mantero F, Funder JW: In-vivo metabolites of spironolactone and potassium canrenoate: determination of potential anti-androgenic activity by a mouse kidney cytosol receptor assay. Clin Endocrinol (Oxf) 1985, 23:341-7.

45. Francavilla A, Di Leo A, Eagon PK, Polimeno L, Guglielmi F, Fanizza G, Barone M, Starzl TE: Effect of spironolactone and potassium canrenoate on cytosolic and nuclear androgen and estrogen receptors of rat liver. Gastroenterology 1987, 93:68I-6.

46. Caprio M, Newfell BG, La Sala A, Baur W, Fabbri A, Rosano G, Mendelsohn ME, Jaffe IZ: Functional mineralocorticoid receptors in human vascular endothelial cells regulate intercellular adhesion molecule-I expression and promote leukocyte adhesion. Circ Res 2008, 102:1359-67.

47. Rigsby CS, Ergul A, Portik Dobos V, Pollock DM, Dorrance AM: Effects of spironolactone on cerebral vessel structure in rats with sustained hypertension. Am J Hypertens 20II, 24:708-I5.

48. Hatakeyama H, Inaba S, Takeda R, Miyamori I: I I beta-hydroxysteroid dehydrogenase in human vascular cells. Kidney Int 2000, 57:1352-7.

49. Hatakeyama H, Inaba S, Miyamori I: I I beta-hydroxysteroid dehydrogenase in cultured human vascular cells. Possible role in the development of hypertension. Hypertension 1999, 33: I 179-84.

50. Brem AS, Bina RB, King TC, Morris DJ: Localization of 2 I I betaOH steroid dehydrogenase isoforms in aortic endothelial cells. Hypertension 1998, 3 1:459-62.

5I. Gong R, Morris DJ, Brem AS: Variable expression of I Ibeta Hydroxysteroid dehydrogenase (I I beta-HSD) isoforms in vascular endothelial cells. Steroids 2008, 73: I I87-96.

52. Young MJ, Moussa L, Dilley R, Funder JW: Early inflammatory responses in experimental cardiac hypertrophy and fibrosis: effects of II beta-hydroxysteroid dehydrogenase inactivation. Endocrinology 2003, I44: I I2I-5.

53. Wilson P, Morgan J, Funder JW, Fuller PJ, Young MJ: Mediators of mineralocorticoid receptor-induced profibrotic inflammatory responses in the heart. Clin Sci 2009, I I6:731-9.

54. Rickard AJ, Young MJ: Corticosteroid receptors, macrophages and cardiovascular disease. J Mol Endocrinol 2009, 42:449-59.

55. Rickard AJ, Morgan J, Tesch G, Funder JW, Fuller PJ, Young MJ: Deletion of mineralocorticoid receptors from macrophages protects against deoxycorticosterone/salt-induced cardiac fibrosis and increased blood pressure. Hypertension 2009, 54:537-43.

\section{FIOOOPrime
RECOMMENDED}

56. Usher MG, Duan SZ, Ivaschenko CY, Frieler RA, Berger S, Schütz G, Lumeng CN, Mortensen RM: Myeloid mineralocorticoid receptor controls macrophage polarization and cardiovascular hypertrophy and remodeling in mice. J Clin Invest 2010, 1 20:3350-64.

\section{FlOOOPrime

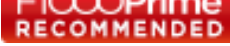

57. Lim H, Müller N, Herold MJ, van den Brandt, Jens, Reichardt HM: Glucocorticoids exert opposing effects on macrophage 
function dependent on their concentration. Immunology 2007, 1 22:47-53.

\section{FIOOOPrime}

58. Armanini D, Strasser T, Weber PC: Binding of agonists and antagonists to mineralocorticoid receptors in human peripheral mononuclear leucocytes. J Hypertens Suppl I985, 3:SI 57-9.

59. Labuzek K, Liber S, Bułdak L, Krupej-Kędzierska J, Machnik G, Bobrzyk M, Okopień B: Eplerenone mimics features of the alternative activation in macrophages obtained from patients with heart failure and healthy volunteers. Eur J Pharmacol 2014, 726C:96-108.

\section{FIOOOPrime} RECOMMENDED

60. Łabuzek K, Liber S, Bułdak Ł, Machnik G, Liber J, Okopień B: Eplerenone promotes alternative activation in human monocyte-derived macrophages. Pharmacol Rep 2013, 65:226-34.

\section{FlOOPrime} RECOMMENDED

6I. Guzik TJ, Hoch NE, Brown KA, McCann LA, Rahman A, Dikalov S, Goronzy J, Weyand C, Harrison DG: Role of the $\mathbf{T}$ cell in the genesis of angiotensin II induced hypertension and vascular dysfunction. J Exp Med 2007, 204:2449-60.

\section{FlOOOPrime
RECOMMENDED}

62. Amador CA, Barrientos V, Peña J, Herrada AA, González M, Valdés S, Carrasco L, Alzamora R, Figueroa F, Kalergis AM, Michea L: Spironolactone decreases DOCA-salt-induced organ damage by blocking the activation of $\mathrm{T}$ helper 17 and the downregulation of regulatory T lymphocytes. Hypertension 2014, 63:797-803.

\section{FlOOOPrime
RECOMMENDED}

63. van den Meiracker, Anton H, Baggen RG, Pauli S, Lindemans A, Vulto AG, Poldermans D, Boomsma F: Spironolactone in type 2 diabetic nephropathy: Effects on proteinuria, blood pressure and renal function. J Hypertens 2006, 24:2285-92.

64. Samuel J, Delcayre C: Heart failure: aldosterone antagonists are underused by clinicians. Nat Rev Cardiol 2010, 7:125-7.

65. McMurray, John JV, Adamopoulos S, Anker SD, Auricchio A, Böhm M, Dickstein K, Falk V, Filippatos G, Fonseca C, Gomez-Sanchez MA, Jaarsma T, Køber L, Lip, Gregory Y H, Maggioni AP, Parkhomenko A, Pieske BM, Popescu BA, Rønnevik PK, Rutten FH, Schwitter J, Seferovic P, Stepinska J, Trindade PT, Voors AA, Zannad F, Zeiher A: ESC Guidelines for the diagnosis and treatment of acute and chronic heart failure 20 I 2: The Task Force for the Diagnosis and Treatment of Acute and Chronic Heart Failure 2012 of the European Society of Cardiology. Developed in collaboration with the Heart Failure Association (HFA) of the ESC. Eur Heart J 2012, 33: 1787-847.

\section{FlOOOPrime RECOMMENDED}

66. Hunt SA, Abraham WT, Chin MH, Feldman AM, Francis GS, Ganiats TG, Jessup M, Konstam MA, Mancini DM, Michl K, Oates JA, Rahko PS, Silver MA, Stevenson LW, Yancy CW: 2009 Focused update incorporated into the ACC/AHA 2005 Guidelines for the Diagnosis and Management of Heart Failure in Adults A Report of the American College of Cardiology Foundation/American Heart Association Task Force on Practice Guidelines Developed in Collaboration With the International Society for Heart and Lung Transplantation. J Am Coll Cardiol 2009, 53:el-e90.

\section{FlOOOPrime} RECOMMENDED

67. Vaduganathan M, Fonarow GC, Gheorghiade M: Drug therapy to reduce early readmission risk in heart failure: ready for prime time? JACC Heart Fail 2013, I:361-4.
68. Talatinian A, Chow SL, Heywood JT: Expanding role of mineralocorticoid receptor antagonists in the treatment of heart failure. Pharmacotherapy 2012, 32:827-37.

69. Kolkhof P, Borden SA: Molecular pharmacology of the mineralocorticoid receptor: prospects for novel therapeutics. Mol Cell Endocrinol 2012, 350:310-7.

70. Arhancet GB, Woodard SS, Dietz JD, Garland DJ, Wagner GM, lyanar K, Collins JT, Blinn JR, Numann RE, Hu X, Huang H: Stereochemical requirements for the mineralocorticoid receptor antagonist activity of dihydropyridines. J Med Chem 2010, 53:4300-4.

7I. Dietz JD, Du S, Bolten CW, Payne MA, Xia C, Blinn JR, Funder JW, $\mathrm{Hu} X$ : A number of marketed dihydropyridine calcium channel blockers have mineralocorticoid receptor antagonist activity. Hypertension 2008, 51:742-8.

\section{FlOOOPrime}

\section{RECOMMENDED}

72. Kosaka H, Hirayama K, Yoda N, Sasaki K, Kitayama T, Kusaka $H$ Matsubara M: The L-, $\mathbf{N}$-, and T-type triple calcium channel blocker benidipine acts as an antagonist of mineralocorticoid receptor, a member of nuclear receptor family. Eur J Pharmacol 2010, 635:49-55.

73. Matsui T, Takeuchi M, Yamagishi S: Nifedipine, a calcium channel blocker, inhibits inflammatory and fibrogenic gene expressions in advanced glycation end product (AGE)-exposed fibroblasts via mineralocorticoid receptor antagonistic activity. Biochem Biophys Res Commun 2010, 396:566-70.

74. Bärfacker L, Kuhl A, Hillisch A, Grosser R, Figueroa-Pérez S, Heckroth H, Nitsche A, Ergüden J, Gielen-Haertwig H, Schlemmer K, Mittendorf J, Paulsen H, Platzek J, Kolkhof P: Discovery of BAY 94-8862: a nonsteroidal antagonist of the mineralocorticoid receptor for the treatment of cardiorenal diseases. ChemMedChem 2012, 7:1385-403.

75. Pitt B, Filippatos G, Gheorghiade M, Kober L, Krum H, Ponikowski P, Nowack C, Kolkhof P, Kim S, Zannad F: Rationale and design of ARTS: a randomized, double-blind study of BAY 94-8862 in patients with chronic heart failure and mild or moderate chronic kidney disease. Eur J Heart Fail 2012, I4:668-75.

76. Pitt B, Kober L, Ponikowski P, Gheorghiade M, Filippatos G, Krum H, Nowack C, Kolkhof P, Kim S, Zannad F: Safety and tolerability of the novel non-steroidal mineralocorticoid receptor antagonist BAY 94-8862 in patients with chronic heart failure and mild or moderate chronic kidney disease: a randomized, double-blind trial. Eur Heart J 2013, 34:2453-63.

\section{FlOOOPrime}

RECOMMENDED

77. Bauersachs J: The ARTS of third-generation mineralocorticoid receptor antagonists: achieving cardiovascular benefit with minimized renal side effects? Eur Heart J 20I3, 34:2426-8.

78. Kolkhof P, Delbeck M, Kretschmer A, Steinke W, Hartmann E, Bärfacker L, Eitner F, Albrecht-Küpper B, Schäfer S: Finerenone, a novel selective non-steroidal mineralocorticoid receptor antagonist protects from rat cardiorenal injury. J Cardiovasc Pharmacol 2014.

79. Cerny MA: Progress towards clinically useful aldosterone synthase inhibitors. Curr Top Med Chem 2013, I3:I385-40I.

\section{FIOOOPrime
RECOMMENDED}

80. Bomback AS, Klemmer PJ: The incidence and implications of aldosterone breakthrough. Nat Clin Pract Nephrol 2007, 3:486-92.

81. Nobakht N, Kamgar M, Rastogi A, Schrier RW: Limitations of angiotensin inhibition. Nat Rev Nephrol 201 I, 7:356-9.

82. Mornet E, Dupont J, Vitek A, White PC: Characterization of two genes encoding human steroid I I beta-hydroxylase (P-450( I I) beta). J Biol Chem 1989, 264:2096I-7.

83. Ménard J, Gonzalez M, Guyene T, Bissery A: Investigation of aldosterone-synthase inhibition in rats. J Hypertens 2006, 24: | |47-55. 
84. Fiebeler A, Nussberger J, Shagdarsuren E, Rong S, Hilfenhaus G, Al-Saadi N, Dechend R, Wellner M, Meiners S, Maser-Gluth C, Jeng AY, Webb RL, Luft FC, Muller DN: Aldosterone synthase inhibitor ameliorates angiotensin II-induced organ damage. Circulation 2005, III :3087-94.

85. Mulder P, Mellin V, Favre J, Vercauteren M, Remy-Jouet I, Monteil C, Richard V, Renet S, Henry JP, Jeng AY, Webb RL, Thuillez C: Aldosterone synthase inhibition improves cardiovascular function and structure in rats with heart failure: a comparison with spironolactone. Eur Heart J 2008, 29:2171-9.

86. Lea WB, Kwak ES, Luther JM, Fowler SM, Wang Z, Ma J, Fogo AB, Brown NJ: Aldosterone antagonism or synthase inhibition reduces end-organ damage induced by treatment with angiotensin and high salt. Kidney Int 2009, 75:936-44.

\section{FlOOOPrime} RECOMMENDED

87. Hargovan M, Ferro A: Aldosterone synthase inhibitors in hypertension: current status and future possibilities. JRSM Cardiovasc Dis 20I4, 3:20480040 I 4522440 .

88. Amar L, Azizi M, Menard J, Peyrard S, Watson C, Plouin P: Aldosterone synthase inhibition with LCI699: a proof-of-concept study in patients with primary aldosteronism. Hypertension 2010, 56:83I-8.

89. Calhoun DA, White WB, Krum H, Guo W, Bermann G, Trapani A, Lefkowitz MP, Ménard J: Effects of a novel aldosterone synthase inhibitor for treatment of primary hypertension: results of a randomized, double-blind, placebo- and active-controlled phase 2 trial. Circulation 2011, 124:1945-55.

90. Andersen K, Hartman D, Peppard T, Hermann D, van Ess P, Lefkowitz $M$, Trapani $A$ : The effects of aldosterone synthase inhibition on aldosterone and cortisol in patients with hypertension: a phase II, randomized, double-blind, placebocontrolled, multicenter study. J Clin Hypertens (Greenwich) 2012, I4:580-7.

91. Karns AD, Bral JM, Hartman D, Peppard T, Schumacher C: Study of aldosterone synthase inhibition as an add-on therapy in resistant hypertension. J Clin Hypertens (Greenwich) 2013, 15: 186-92.

92. Amar L, Azizi M, Menard J, Peyrard S, Plouin P: Sequential comparison of aldosterone synthase inhibition and mineralocorticoid blockade in patients with primary aldosteronism. J Hypertens 2013, 3 1:624-9; discussion 629.

93. Bertagna X, Pivonello R, Fleseriu M, Zhang Y, Robinson P, Taylor A, Watson CE, Maldonado M, Hamrahian AH, Boscaro M, Biller, Beverly M $\mathrm{K}$ : $\mathrm{LCl699}$, a potent II $\beta$-hydroxylase inhibitor, normalizes urinary cortisol in patients with Cushing's disease: results from a multicenter, proof-of-concept study. J Clin Endocrinol Metab 2014, 99:1375-83

94. Williams JS: Evolving research in nongenomic actions of aldosterone. Curr Opin Endocrinol Diabetes Obes 2013, 20:198-203.

95. Wendler A, Albrecht C, Wehling M: Nongenomic actions of aldosterone and progesterone revisited. Steroids 20I2, 77: I002-6.

96. Grossmann C, Gekle M: New aspects of rapid aldosterone signaling. Mol Cell Endocrinol 2009, 308:53-62.

\section{FIOOOPrime}

97. Dooley R, Harvey BJ, Thomas W: Non-genomic actions of aldosterone: from receptors and signals to membrane targets. Mol Cell Endocrinol 20I2, 350:223-34.

98. Christ M, Eisen C, Aktas J, Theisen K, Wehling M: The inositolI,4,5-trisphosphate system is involved in rapid effects of aldosterone in human mononuclear leukocytes. J Clin Endocrinol Metab 1993, 77: |452-7.

99. Christ M, Meyer C, Sippel K, Wehling M: Rapid aldosterone signaling in vascular smooth muscle cells: involvement of phospholipase C, diacylglycerol and protein kinase C alpha. Biochem Biophys Res Commun 1995, 213:123-9.

100. Christ M, Günther A, Heck M, Schmidt BM, Falkenstein E, Wehling M: Aldosterone, not estradiol, is the physiological agonist for rapid increases in CAMP in vascular smooth muscle cells. Circulation 1999, 99:1485-91.
I0I. Wehling M, Neylon CB, Fullerton M, Bobik A, Funder JW: Nongenomic effects of aldosterone on intracellular $\mathrm{Ca} 2+$ in vascular smooth muscle cells. Circ Res 1995, 76:973-9.

102. Gekle M, Freudinger R, Mildenberger S, Schenk K, Marschitz I, Schramek H: Rapid activation of $\mathbf{N a}+/ \mathbf{H}+-e x c h a n g e$ in MDCK cells by aldosterone involves MAP-kinase ERK I/2. Pflugers Arch 200I, 44I:78I-6.

103. McEneaney V, Dooley R, Harvey BJ, Thomas W: Protein kinase D stabilizes aldosterone-induced ERK I/2 MAP kinase activation in $\mathrm{MI}$ renal cortical collecting duct cells to promote cell proliferation. J Steroid Biochem Mol Biol 2010, I I 8: 18-28.

104. Callera GE, Montezano, Augusto C I, Yogi A, Tostes RC, He Y, Schiffrin EL, Touyz RM: c-Src-dependent nongenomic signaling responses to aldosterone are increased in vascular myocytes from spontaneously hypertensive rats. Hypertension 2005, 46: 1032-8.

105. Callera GE, Touyz RM, Tostes RC, Yogi A, He Y, Malkinson S, Schiffrin EL: Aldosterone activates vascular p38MAP kinase and NADPH oxidase via c-Src. Hypertension 2005, 45:773-9.

106. GotoJ, Otsuka F, Yamashita M, Suzuki J, Otani H, Takahashi H, Miyoshi T, Mimura $Y$, Ogura T, Makino H: Enhancement of aldosteroneinduced catecholamine production by bone morphogenetic protein-4 through activating Rho and SAPK/JNK pathway in adrenomedullar cells. Am J Physiol Endocrinol Metab 2009, 296: E904-16.

107. Gros R, Ding Q, Liu B, Chorazyczewski J, Feldman RD: Aldosterone mediates its rapid effects in vascular endothelial cells through GPER activation. Am J Physiol Cell Physiol 2013, 304:C532-40.

\section{FlOOOPrime}

RECOMMENDED

108. Gros R, Ding Q, Davis M, Shaikh R, Liu B, Chorazyczewski J, Pickering JG, Feldman RD: Delineating the receptor mechanisms underlying the rapid vascular contractile effects of aldosterone and estradiol. Can J Physiol Pharmacol 20II, 89:655-63.

\section{FlOOOPrime
RECOMMENDED}

109. Bologa CG, Revankar CM, Young SM, Edwards BS, Arterburn JB, Kiselyov AS, Parker MA, Tkachenko SE, Savchuck NP, Sklar LA, Oprea TI, Prossnitz ER: Virtual and biomolecular screening converge on a selective agonist for GPR30. Nat Chem Biol 2006, 2:207-12.

\section{FlOOOPrime \\ RECOMMENDED}

110. Dennis MK, Burai R, Ramesh C, Petrie WK, Alcon SN, Nayak TK, Bologa CG, Leitao A, Brailoiu E, Deliu E, Dun NJ, Sklar LA, Hathaway HJ, Arterburn JB, Oprea TI, Prossnitz ER: In vivo effects of a GPR30 antagonist. Nat Chem Biol 2009, 5:421-7.

\section{FlOOOPrime
RECOMMENDED}

III. Lindsey SH, Cohen JA, Brosnihan KB, Gallagher PE, Chappell MC: Chronic treatment with the $\mathbf{G}$ protein-coupled receptor 30 agonist G-I decreases blood pressure in ovariectomized mRen2.Lewis rats. Endocrinology 2009, I50:3753-8.

\section{FlOOOPrime}

RECOMMENDED

I12. Lindsey SH, Carver KA, Prossnitz ER, Chappell MC: Vasodilation in response to the GPR30 agonist G-I is not different from estradiol in the mRen2.Lewis female rat. J Cardiovasc Pharmacol 20II, 57:598-603.

\section{FlOOOPrime
RECOMMENDED}

II3. Toda N, Nakanishi S, Tanabe S: Aldosterone affects blood flow and vascular tone regulated by endothelium-derived NO: therapeutic implications. Br J Pharmacol 2013, 168:519-33.

II4. Jaffe IZ, Jaisser F: Endothelial cell mineralocorticoid receptors: turning cardiovascular risk factors into cardiovascular dysfunction. Hypertension 2014, 63:915-7. 
115. McCurley A, Jaffe IZ: Mineralocorticoid receptors in vascular function and disease. Mol Cell Endocrinol 20I2, 350:256-65.

116. Heylen E, Huang A, Sun D, Kaley G: Nitric oxide-mediated dilation of arterioles to intraluminal administration of aldosterone. J Cardiovasc Pharmacol 2009, 54:535-42.

FIOOOPrime

1 17. Weber KT, Brilla CG, Janicki JS, Reddy HK, Campbell SE: Myocardial fibrosis: role of ventricular systolic pressure, arterial hypertension, and circulating hormones. Basic Res Cardiol 1991, 86 (Suppl 3):25-31.

I 18. Campbell SE, Diaz-Arias AA, Weber KT: Fibrosis of the human heart and systemic organs in adrenal adenoma. Blood Press 1992, I:149-56.

1 19. Brilla CG, Weber KT: Mineralocorticoid excess, dietary sodium, and myocardial fibrosis. J Lab Clin Med I 992, I 20:893-90I.

120. Weber KT, Villarreal D: Aldosterone and antialdosterone therapy in congestive heart failure. Am J Cardiol I993, 7 I:3A- I IA.

121. Brilla CG, Matsubara LS, Weber KT: Anti-aldosterone treatment and the prevention of myocardial fibrosis in primary and secondary hyperaldosteronism. J Mol Cell Cardiol 1993, 25:563-75.

122. Gordon RD, Stowasser M, Tunny TJ, Klemm SA, Rutherford JC: High incidence of primary aldosteronism in 199 patients referred with hypertension. Clin Exp Pharmacol Physiol 1994, 21:315-8.
123. Lim PO, Rodgers P, Cardale K, Watson AD, MacDonald TM: Potentially high prevalence of primary aldosteronism in a primary-care population. Lancet 1999, 353:40.

124. Rossi GP, Bernini G, Caliumi C, Desideri G, Fabris B, Ferri C, Ganzaroli C, Giacchetti G, Letizia C, Maccario M, Mallamaci F, Mannelli M, Mattarello M, Moretti A, Palumbo G, Parenti G, Porteri E, Semplicini A, Rizzoni D, Rossi E, Boscaro M, Pessina AC, Mantero F: A prospective study of the prevalence of primary aldosteronism in I, I 25 hypertensive patients. J Am Coll Cardiol 2006, 48:2293-300.

\section{FlOOOPrime}

RECOMMENDED

125. Fardella CE, Mosso L, Gómez-Sánchez C, Cortés P, Soto J, Gómez L, Pinto M, Huete A, Oestreicher E, Foradori A, Montero J: Primary hyperaldosteronism in essential hypertensives: prevalence, biochemical profile, and molecular biology. J Clin Endocrinol Metab 2000, 85: 1863-7.

126. Connell, John MC, Fraser R, MacKenzie S, Davies E: Is altered adrenal steroid biosynthesis a key intermediate phenotype in hypertension? Hypertension 2003, 41 :993-9.

127. Yagi S, Akaike M, Aihara K, Iwase T, Yoshida S, Sumitomo-Ueda Y, Ikeda Y, Ishikawa K, Matsumoto T, Sata M: High plasma aldosterone concentration is a novel risk factor of cognitive impairment in patients with hypertension. Hypertens Res 201 I, 34:74-8.

\section{FlOOOPrime}

